\title{
Effects of diabetes mellitus type I on skeletal muscle: an integrative review
}

\author{
SANTOS, A. J. C. A. ${ }^{*}$, SILVA, E. L. A. ${ }^{2}$, ALBUQUERQUE, Y. M. L. ${ }^{2}$, \\ OLIVEIRA, B. D. R. ${ }^{3}$ and CAIAFFO, V. ${ }^{1}$
}

\author{
${ }^{1}$ Department of Animal Morphology and Physiology, Universidade Federal Rural de Pernambuco - UFRPE, \\ Rua Dom Manoel de Medeiros, s/n, Dois Irmãos, CEP 52171-900, Recife, PE, Brazil \\ ${ }^{2}$ Department of Biology, Universidade Federal Rural de Pernambuco - UFRPE, Rua Dom Manoel de Medeiros, \\ $\mathrm{s} / \mathrm{n}$, Dois Irmãos, CEP 52171-900, Recife, PE, Brazil \\ ${ }^{3}$ Department of Physiotherapy, Associação Caruaruense de Ensino - ASCES, \\ Avenida Portugal, 584, Mauricio de Nassau, CEP 55016-400, Caruaru, PE, Brazil \\ *E-mail: ardillesjuan@hotmail.com
}

\begin{abstract}
Introduction: The Diabetes Mellitus (DM) is considered a serious public health problem in Brazil and in the world, increased by the modern life style, characterized by reduced physical activity, increased obesity and aging of the population. The diabetic myopathy is characterized as a complication in the striated skeletal muscles caused by diabetes, characterized by decreased muscle mass, weakness and reduced physical capacity. Thus the present study aimed to review in the literature the main changes suffered by muscle cells associated with Diabetes Mellitus type I. Material and Methods: The present review regards to the major studies in digital databases about the effects of DM type I on the morphology of the skeletal muscles. The search for references was performed in the following databases: Medical Literature and Retrieval System Online (MEDLINE/ PUBMED), Google Scholar and Scientific Electronic Library Online (SCIELO). Articles should have the following criteria to enter in the research: articles published in the last ten years, in English, Portuguese or Spanish and available online. Results: The database that had the highest number of publications was MEDLINE (98), followed by SCIELO (56) and Google Scholar (43). Only, 4 articles were selected. The articles were described according to the year of publication, title of work, journal and objectives. Conclusion: This review shows a clear association between diabetes mellitus type I and changes in skeletal muscle. The risks of atrophy in the muscles, especially the members, were significantly higher in patients with this syndrome than in normal patients. Which makes the issue of fundamental importance to the area of health.
\end{abstract}

Keywords: diabetes mellitus, diabetic myopathy, skeletal muscle.

\section{Introduction}

Diabetes Mellitus (DM) is a systemic disease that occurs when the release of insulin from pancreatic beta-cell fails to maintain glucose levels in the blood under normal conditions (D'ALEO, MANCARELLA, GUERRA et al., 2011). This disease is a disorder of metabolism of proteins, carbohydrates and fats due to functional deficiency of insulin, which can be characterized by an elevation of blood glucose. This causes abnormal metabolism hyperglycemia, resulting in a high risk of visual complications, kidney and neurological (NATHAN, 2009).

The DM is considered a serious public health problem in Brazil and in the world (FRANCIONI and SILVA, 2007), increased by the modern life style, characterized by reduced physical activity, increased obesity and aging of the population (WHITING, GUARIGUATA, WEIL et al., 2011). There are several classifications for DM. But the major ones are the DM I and DM II. Type I is the result of destruction of pancreatic islets and occurs in 5 to $10 \%$ of cases. Type II is the most common and outcome defects in the secretion and/or insulin action. Both types of diabetes mellitus cause similar health complications however are different concerning to pathogenic processes (SALTIER and KAHN, 2001).
The DM is responsible for numerous vascular complications that compromise the survival rate of patients (ALVIN, 2004). The DM type I is commonly associated with numerous pathological complications such as macrovascular disease, neuropathy, nephropathy and retinopathy (BROWNLEE, 2005). Musculoskeletal complications, myopathies, are also found and, even though less valued than the vascular one, compromises the quality of life of patients (SAVAS, KÖROĞLU, KOYUNCUOĞLU et al., 2007). It is a clinical condition commonly characterized by a smaller muscle mass, weakness and reduced physical capacity (ANDERSEN, SCHMITZ and NIELSEN, 2005).

Considering that Diabetes Mellitus type I and II have a high prevalence worldwide and it is a complex diseases involving intrinsic and extrinsic factors to the individual. Thus it becomes fundamental to research its complications in different body tissues. Complications of skeletal muscle tissue are not as investigated as complications in other tissues. Therefore the present study aimed to carry out an integrative literature review, analyzing the studies that have been conducted on the effects of DM type I on the morphology of the skeletal muscle. 


\section{Materials and Methods}

The present review regards to the major studies in digital databases about the effects of DM type I on the morphology of the skeletal muscles. The search for references was performed in the following databases: Medical Literature and Retrieval System Online (MEDLINE/ PUBMED), Google Scholar e Scientific Electronic Library Online (SCIELO). Articles should have the following criteria to enter in the research: articles published in the last ten years, in English, Portuguese or Spanish and available online.

The research for articles occurred between May and July of 2013 and the following keywords were utilized: Diabetes mellitus type I and skeletal muscle. The research resulted in a total of 246 items. An initial reading of the title and abstracts was made to see if the articles would suit the criteria of inclusion in the research: full articles available online in the period of 2003 to 2013 and that the abstracts were directly related to the theme proposed by the research. Articles that included more than one pathology besides diabetes, literature review articles, articles related to the association of diabetes to other structures besides the skeletal muscle were excluded from the research. At the end of this step nine articles were selected to participate in the research.

Posteriorly all of the pre-selected articles were evaluated with the following criteria: objectives, procedures used during the research, analyzing the results and finally the relevance of research.

The articles were classified in 1 and 2. Classification 1 refers to articles with a satisfactory methodology that had some disagreements regarding the proposed theme, such as: use of certain drugs in synergy with the DM I, effect of exercise on skeletal muscle of patients with DM I, among many other methodologies. Classification 2 refers to articles with a satisfactory methodology and that had suited well the proposed theme. At the end of this step 4 articles were selected. The articles were described according to the year of publication, title of work, journal and objectives.

\section{Results and Discussion}

The database that had the highest number of publications was MEDLINE (98), followed by SCIELO (56) and Google Scholar (43) (Table 1). The articles were found mostly in the English in the database Pub Med / Medline.

In Table 2 we can observe a distribution of the articles by the following criteria: title, journal where it was published and the year of publication, and the research objectives.

In general in our search it was found a clear association between diabetes mellitus type I and changes in skeletal muscle. The risks of atrophy in the muscles, especially the members, were significantly higher in patients with this syndrome than in normal patients. Therefore, this review highlights the relationship between DM I and changes in skeletal muscle, which a subject of fundamental importance to the field of Health.

In the study of Krause, Riddell and Hawke (2011) the effects of DM I of the skeletal muscle were analyzed by clinical observations and tests in experimental models in rats. The results of these tests showed a clear association between DM I and their pathological effects in skeletal muscle. It were found alterations in the absence of actin and myosin molecules responsible for muscle contraction, changes in muscle fiber type I (slow-twitch fibers) and fibers muscle type II (fast twitch fibers).

Glauser, Glauser and Hatem (2008) studied the relationship between muscle infarction and its association with DM I

Table 1. Distribution of the articles in the databases.

\begin{tabular}{lcccc}
\multicolumn{1}{c}{ Database } & Articles & Pre-selected & Excluded & Annalized \\
\hline SCIELO & 56 & 12 & 12 & 0 \\
GOOGLE SCHOLAR & 43 & 6 & 6 & 0 \\
MEDLINE & 98 & 10 & 6 & 4 \\
TOTAL & & & & 4 \\
\hline
\end{tabular}

Table 2. Distribution of articles with titles, journals / year and objectives. Arranged in ascending order of years.

\begin{tabular}{|c|c|c|c|}
\hline REFERENCE & TITLE & JOURNAL/YEAR & OBJETIVES \\
\hline $\begin{array}{l}\text { Andersen, Gjerstad and } \\
\text { Jakobsen (2004) }\end{array}$ & $\begin{array}{l}\text { Atrophy of foot muscles: } \\
\text { a measure of diabetic } \\
\text { neuropathy. }\end{array}$ & $\begin{array}{l}\text { Diabetes Care. 2004; 27: } \\
\text { 2382-2385. }\end{array}$ & $\begin{array}{l}\text { Evaluate the atrophy of the } \\
\text { foot muscles and its degree } \\
\text { in diabetic patients. }\end{array}$ \\
\hline $\begin{array}{l}\text { Glauser, Glauser and Hatem } \\
(2008)\end{array}$ & $\begin{array}{l}\text { Diabetic muscle infarction: } \\
\text { a rare complication of } \\
\text { advanced diabetes mellitus. }\end{array}$ & $\begin{array}{l}\text { Emerg. Radiol. 2008; 15: } \\
61-65 .\end{array}$ & $\begin{array}{l}\text { Evaluate the effects of type } \\
\text { I diabetes on the skeletal } \\
\text { muscle through MRI. }\end{array}$ \\
\hline $\begin{array}{l}\text { Krause, Riddell and Hawke } \\
(2011)\end{array}$ & $\begin{array}{l}\text { Effects of type } 1 \text { diabetes } \\
\text { mellitus on skeletal } \\
\text { muscle: clinical observations } \\
\text { and physiological } \\
\text { mechanisms. }\end{array}$ & $\begin{array}{l}\text { Pediatric Diabetes. 2001; } 12 \text { : } \\
345-364 \text {. }\end{array}$ & $\begin{array}{l}\text { To study the effects of } \\
\text { diabetes mellitus type } \\
\text { I in skeletal muscle by } \\
\text { clinical and physiological } \\
\text { observations. }\end{array}$ \\
\hline $\begin{array}{l}\text { Ramchurn, Mashamba, } \\
\text { Leitch et al. (2009) }\end{array}$ & $\begin{array}{l}\text { Upper limb muscle skeletal } \\
\text { abnormalities and poor } \\
\text { metabolic control in } \\
\text { diabetes. }\end{array}$ & $\begin{array}{l}\text { European of Int. Medicine. } \\
\text { 2009; 20: 718-721. }\end{array}$ & $\begin{array}{l}\text { Analyze the effects of loss of } \\
\text { glycemic control in diabetic } \\
\text { patients through skeletal } \\
\text { muscle response. }\end{array}$ \\
\hline
\end{tabular}


through radiology of patients with diabetes and normal patients, demonstrating that patients with this syndrome have $50 \%$ more chance of having a muscular infarct than normal patients, mainly in the muscles of the thigh and back of the leg (calf).

Ramchurn, Mashamba, Leitch et al. (2009) in a study of 100 diabetic patients ( 50 patients with DM I and 50 patients with DM II), conducted tests to determine the prevalence of musculoskeletal disorders in patients with DM I and DM II. It was observed that patients with diabetes had some musculoskeletal conditions, such as: Carpo tunnel syndrome present in $20 \%$ of diabetic patients, shoulder capsulitis more common in patients with DM II compared to DM I (39\% and $11 \%$ respectively), thickening of the tendons of insertion, joint mobility reduced among other pathological changes triggered by diabetes compared to normal patients. Andersen, Gjerstad and Jakobsen (2004) made a comparison of the volume of muscle mass in diabetic patients with diabetic Neuropathy among patients with DM I, who did not have Neuropathy diabetic, and healthy patients. He found that diabetic patients with diabetic Neuropathy had a considerable loss of muscle volume and that diabetic patients without diabetic Neuropathy and healthy patients presented no significant difference related to the loss of muscle mass.

From what has been seen, it is noticed that the studies relating the DM I and changes in skeletal muscles are still very limited, since the methodologies used in articles vary significantly. Therefore, there is a need for more studies about this relationship, to better determine the relationship between diabetes and its effects on skeletal muscle.

\section{Conclusion}

Although the search for articles held in the databases very few articles were found. The evaluation of the quality of the articles found in our review was evaluated through a critical reading of the articles, with some established parameters that guided our choice by articles. It was then possible to detect the main limitations of the studies analyzed, helping to show new perspectives of research on this subject. Thus we have seen that more research is needed with more standardized criteria and more significant samples since most of the studies used small samples compromising the statistical analysis of the data from these studies. Therefore this article brings up important questions about the effects of type I Diabetes Mellitus on the skeletal muscle. Hence further research is still required to update and improve studies about the changes of striated muscle caused by DM I aiming to bring new perspectives to the study and treatment of people with this syndrome, helping the lives and improving the health of them.

\section{References}

ALVIN, CP. Diabetes mellitus. In KASPER, DL., BRAUNWALD, E., FAUCI, A., HAUSER, S., LONGO, D, and JAMESON, JL. (Eds.). Harrison's principle of internal medicine. New York: McGraw-Hill, 2004. vol. 16, p. 3779-829.

ANDERSEN, H., GJERSTAD, MD. and JAKOBSEN, J. Atrophy of foot muscles: a measure of diabetic neuropathy. Diabetes Care, 2004, vol. 27 , p. 2382-2385

ANDERSEN, H., SCHMITZ, O. and NIELSEN, S. Decreased isometric muscle strength after acute hyperglycaemia in type 1 diabetic patients. Diabetic Medicine, 2005, vol. 22, p. 1401-1407.

BROWNLEE, M. The pathobiology of diabetic complications: a unifying mechanism. Diabetes, 2005, vol. 54, p. 1615-1625.

D'ALEO, A., MANCARELLA, R., GUERRA, SD., BOGGI, U., FILIPPONI, F., MARCHETTI, P. and LUPI, R. Direct effects of rapid-acting insulin analogues on insulin signaling in human pancreatic islets in vitro. Diabetes \& Metabolism, 2011, vol. 37, p. 324-329. http://dx.doi.org/10.1016/j.diabet.2010.12.002.

FRANCIONI, FF. and SILVA, DGV. O processo de viver saudável de pessoas com Diabetes mellitus através de um grupo de convivência. Texto Contexto Enfermagem., 2007, vol. 16, n. 1, p. 105-111.

GLAUSER, SR., GLAUSER, J. and HATEM, SF. Diabetic muscle infarction: a rare complication of advanced diabetes mellitus. Emergency Radiology, 2008, vol. 15, p. 61-65.

KRAUSE, MP., RIDDELL, MC. and HAWKE, TJ. Effects of type 1 diabetes mellitus on skeletal muscle: clinical observations and physiological mechanisms. Pediatric Diabetes, 2011, vol. 12, p. 345-364.

NATHAN, DM. International expert committee report on the role of the AlC Assay in the Diagnosis of Diabetes. Diabetes Care, 2009, vol. 32 , p. 1327-1334.

RAMCHURN, N., MASHAMBA, C., LEITCH, E., ARUTCHELYAM, A., NARAYANAN, K., WEAVER, J., HAMILTON, J., HEYCOCK, C., SARAYANAN, V. and KELLY, C. Upper limb musculo skeletal abnormalities and poor metabolic control in diabetes. European Journal of Internal Medicine, 2009, vol. 20, p. 718-721.

SALTIER, AR. and KAHN, R. Insulin signaling and the regulation of glucose and lipid metabolism. Nature, 2001, vol. 414, p. 799-812.

SAVAS, S., KÖROĞLU, BK., KOYUNCUOĞLU, HR., USAR, E., CELIK, H. and TAMER, NM. The effects of the diabetes related soft tissue hand lesion sand the reduced hand strength on functional disability of hand in type 2 diabetic patients. Diabetes Research and Clinical Practice, 2007, vol. 77, n. 1, p. 77-83.

WHITING, DR., GUARIGUATA, L., WEIL, C. and SHAW, J. IDF diabetes atlas: global estimates of the prevalence of diabetes for 2011 and 2030. Diabetes Research and Clinical Practice, 2011, vol. 94 , p. 311-321. 